\title{
The Relationship Between Hydrogenase and Nitrogenase in Azotobacter chroococcum: Effect of Nitrogen Sources on Hydrogenase Activity
}

\author{
By C. D. P. PARTRIDGE, ${ }^{1}$ C. C. WALKER, ${ }^{2}$ M. G. YATES ${ }^{1 *}$ \\ AND J. R. POSTGATE \\ 1 A.R.C. Unit of Nitrogen Fixation, University of Sussex, Brighton BN1 $9 R Q$ \\ 2 Department of Microbiology, School of Agriculture, University of Edinburgh, \\ Edinburgh EH9 $3 J G$
}

(Received 15 February 1980)

The effects of different nitrogen sources on the $\mathrm{H}_{2}$-uptake hydrogenase activity were studied in batch-grown and carbon- or sulphate-limited chemostat cultures of Azotobacter chroococcum. Hydrogenase activity was significantly higher in $\mathrm{N}_{2}$-fixing than in $\mathrm{NH}_{4}{ }^{+}-$or $\mathrm{NO}_{3}{ }^{-}$-dependent cultures under carbon limitation or in early-stationary phase batch growth but was not influenced by the nitrogen source in sulphate-limited cultures. Hydrogenase activity developed nearly two generation times later than nitrogenase activity during the transition from $\mathrm{NH}_{4}{ }^{+}-$to $\mathrm{N}_{2}$-dependent growth in carbon-limited cultures. A possible explanation is that $\mathrm{H}_{2}$ produced by nitrogenase induced hydrogenase synthesis. Carbonlimited $\mathrm{N}_{2}$-fixing cultures possessed higher hydrogenase activity than did sulphate- or $\mathrm{O}_{2}$-limited cultures. It appears that carbon substrates or metabolites act as primary repressors of hydrogenase activity and that secondary effectors, such as nitrogen sources or $\mathrm{H}_{2}$, act when such repression is removed.

\section{INTRODUCTION}

Wilson and his colleagues in the early 1940s established the presence of an $\mathrm{H}_{2}$-uptake hydrogenase in Azotobacter vinelandii which was most active when the bacteria were fixing $\mathrm{N}_{2}$ (Wilson et al., 1942; Lee et al., 1942; Lee \& Wilson, 1943; Green \& Wilson, 1953). A reason for this relationship became apparent when it was established that the nitrogenase of Azotobacter species produced $\mathrm{H}_{2}$ in vivo: Brotonegoro (1974) and Smith et al. (1976) showed that $\mathrm{N}_{2}$-fixing Azotobacter chroococcum evolved $\mathrm{H}_{2}$ in the presence of $\mathrm{CO}$ and acetylene. Smith et al.(1976) offered the following explanation: $\mathrm{CO}$ inhibited $\mathrm{N}_{2}$ or acetylene reduction by nitrogenase, thus diverting electrons to ATP-dependent $\mathrm{H}_{2}$ production, and $\mathrm{CO}$ plus acetylene inhibited the uptake hydrogenase, thus preventing recycling of $\mathrm{H}_{2}$ formed by nitrogenase. This established a rationale for the apparent association between hydrogenase and nitrogenase.

Several factors, largely recognized by Green \& Wilson (1953), could influence hydrogenase activity and were not taken into account in the experiments by Wilson's group. These include: (1) enzyme activity might change during growth and different nitrogen sources might cause different growth rates; (2) excess $\mathrm{O}_{2}$ may inhibit hydrogenase activity and the optimum $\mathrm{O}_{2}$ concentration for maximum activity may vary with culture density; (3) pH might affect the rate of hydrogenase synthesis and hence activity in the assay, although the experiment of Lee \& Wilson (1943) indicated that the nitrogen source rather than $\mathrm{pH}$ influenced activity; (4) the Knallgass reaction might not reflect the maximum $\mathrm{H}_{2}$-uptake 
capacity of the enzyme and an assay involving fewer intermediate carriers was desirable. To overcome some of these criticisms, Green \& Wilson (1953) measured hydrogenase activity in whole cells and in cell-free extracts with $\mathrm{K}_{3} \mathrm{Fe}(\mathrm{CN})_{6}$ or methylene blue as electron acceptors. Their observations supported the earlier conclusion that the hydrogenase was more active in $\mathrm{N}_{2}$-grown than in $\mathrm{NH}_{4}{ }^{+}$-grown Azotobacter.

Walker \& Yates (1978) showed that carbon-limited continuous cultures of A. chroococcum expressed a higher hydrogenase activity than did $\mathrm{O}_{2^{-}}$or $\mathrm{N}_{2}$-limited cells. This implied that carbon substrates repressed or inhibited hydrogenase synthesis or activity. Repression of uptake hydrogenase activity by carbon substrates has also been observed in Alcaligenes eutrophus (Schlegel \& Eberhardt, 1972) and Rhizobium japonicum (Maier et al., 1978, 1979; Lim \& Shanmugam, 1979). Other factors known to affect hydrogenase activity include $\mathrm{O}_{2}$ and $\mathrm{H}_{2}$ (Yates et al., 1980). Since a reason for a relationship between hydrogenase and nitrogenase has been established and factors affecting hydrogenase activity which were not considered by the early investigators have been discovered, we have re-investigated the effects of nitrogen source on hydrogenase and nitrogenase in both batch and continuous cultures of $A$. chroococcum.

\section{METHODS}

Organism and growth. A non-gummy variant of $A$. chroococcum (NCIB 8003) was grown in batch or continuous cultures at $30^{\circ} \mathrm{C}$ under air (Baker, 1968) in Burk's sucrose medium (Newton et al., 1953) modified to contain $8.2 \mathrm{~mm}$-mannitol instead of sucrose for carbon-limited chemostat cultures or 50 $\mu \mathrm{M}-\mathrm{Na}_{2} \mathrm{SO}_{4}$ for sulphate-limited chemostat cultures. The nitrogen sources were either $\mathrm{NaNO}_{3}$, ammonium acetate or $\mathrm{NH}_{4} \mathrm{Cl}(18 \mathrm{~mm})$ or $\mathrm{N}_{2}$. Carbon- and sulphate-limited chemostats contained 450 and $240 \mathrm{ml}$ culture, respectively. Populations were shown to be carbon- or sulphate-limited by a proportional increase in culture turbidity on increasing the limiting nutrient concentration while retaining a positive dissolved oxygen tension in the cultures $\left(\mathrm{O}_{2}\right.$ was measured by a Uniprobe oxygen electrode and meter). Cultures were grown under $\mathrm{N}_{2}$-fixing conditions at $\mathrm{pH} 6.7 \pm 0.1$, usually at a dilution rate of $0.1 \mathrm{~h}^{-1}$, at $\mathrm{pH} 7.4$ with $\mathrm{NaNO}_{3}$ or ammonium acetate or at $\mathrm{pH} 6.4$ with $\mathrm{NH}_{4} \mathrm{Cl}$. Steady-state turbidities ranged from 0.21 to 0.30 and 0.18 to 0.21 for $\mathrm{N}_{2}$-fixing sulphate- and carbon-limited cultures, respectively, and from 0.54 to 0.60 when the cultures were grown on fixed nitrogen regardless of the source or substrate limitation. Turbidities were measured in a $1 \mathrm{~cm}$ cell at $540 \mathrm{~nm}$ in an EEL colorimeter. Batch cultures were grown either in $100 \mathrm{ml}$ medium in shaken conical flasks $(250 \mathrm{ml})$ for $24 \mathrm{~h}$ or in air-sparged 201 batches at $30^{\circ} \mathrm{C}$. Samples from the latter were harvested during growth.

Nitrogenase and hydrogenase assays. Nitrogenase activity was measured as the rate of acetylene reduction at $30^{\circ} \mathrm{C}$ and interpolated for optimum $\mathrm{O}_{2}$ concentration (Walker \& Yates, 1978) using $5 \mathrm{ml}$ samples from continuous cultures. Hydrogenase activity was determined by two procedures. (1) Activity was measured manometrically in washed cells suspended in phosphate buffer, $\mathrm{pH} 8 \cdot 0$, containing $\mathrm{NaF}(90 \mathrm{~mm})$ and EDTA $(2.4 \mathrm{~mm})$ with methylene blue $(28 \mathrm{~mm})$ as the electron acceptor. EDTA and NaF were added routinely because in pilot experiments with $A$. vinelandii, where hydrogenase was assessed by decolorizing methylene blue, EDTA and NaF stimulated the reaction rate several-fold (F. Simpson \& J. R. Postgate, unpublished observation). EDTA and NaF stimulated hydrogenase activity in manometric assays, where the methylene blue concentration was saturating, only when the cells produced a high concentration of extracellular polysaccharide (C. C. Walker, unpublished observation); nevertheless, as a precaution, they were added to all assays involving methylene blue as an electron acceptor. This assay and that for nitrogenase were assumed to be measures of the hydrogenase and nitrogenase contents of the cells. (2) $\mathrm{H}_{2}$ uptake with $\mathrm{O}_{2}$ as the terminal electron acceptor was measured by injecting $\mathrm{H}^{3} \mathrm{H}$, produced from sodium boro $\left[{ }^{3} \mathrm{H}\right]$ hydride, either into the chemostat in air or into $5 \mathrm{ml}$ samples under $\mathrm{H}_{2}(70 \%)$ and optimum $\mathrm{O}_{2}$ concentration (10 to $15 \%$ depending on the population density and shaking rate) with argon as the normalizing gas. $\mathrm{H}^{3} \mathrm{HO}$ was estimated in a Nuclear Enterprises scintillation counter with NEN 250 as the scintillant.

Assay of nitrogenase peptides. Nitrogenase peptides in whole cells were separated by sodium dodecyl sulphate-polyacrylamide gel electrophoresis (Robson, 1979) and estimated visually after staining with Coomassie blue.

\section{RESULTS}

\section{Hydrogenase activity in batch cultures}

The specific activity of the $\mathrm{H}_{2}$-uptake hydrogenase in batch cultures grown in shake flasks, harvested late in growth, was significantly higher when nitrogenase was derepressed 
Table 1. Effect of different nitrogen sources on the uptake hydrogenase activity of batch cultures of Azotobacter

Results in columns 1 (present investigation) and 4 (from Green \& Wilson, 1953) were obtained by measuring methylene blue-dependent $\mathrm{H}_{2}$ uptake manometrically; those in columns 2 and 3 (from Lee \& Wilson, 1943) were obtained by measuring $\mathrm{O}_{2}$-dependent $\mathrm{H}_{2}$ uptake manometrically. In each case the results are expressed as a percentage of the activity of hydrogenase in an $\mathrm{N}_{2}$-fixing culture since the specific activities were not all expressed in the same units.

\begin{tabular}{|c|c|c|c|c|}
\hline \multirow[b]{3}{*}{ Nitrogen source } & \multicolumn{4}{|c|}{ Relative hydrogenase activity } \\
\hline & \multicolumn{2}{|c|}{ A. chroococcum } & \multicolumn{2}{|c|}{ A. vinelandii } \\
\hline & (1) & (2) & (3) & (4) \\
\hline $\begin{array}{l}\mathrm{N}_{2} \\
\mathrm{NH}_{4}+ \\
\mathrm{NO}_{3}-\end{array}$ & $\begin{array}{c}100 \\
59 \\
48 \cdot 5\end{array}$ & $\begin{array}{c}100 \\
31 \cdot 2 \\
81\end{array}$ & $\begin{array}{c}100 \\
28 \cdot 1 \\
60 \cdot 8\end{array}$ & $\begin{array}{r}100 \\
56\end{array}$ \\
\hline
\end{tabular}

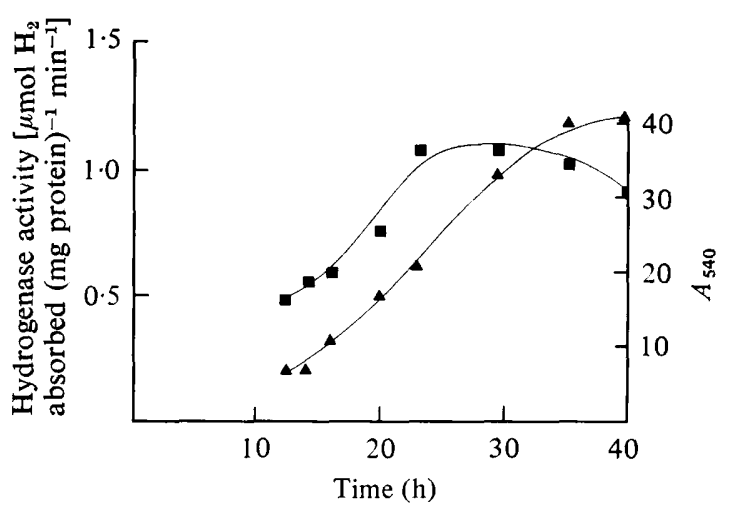

Fig. 1. Uptake hydrogenase activity of $\mathrm{N}_{2}$-fixing $A$. chroococcum in batch culture. Twenty cultures (100 ml each in $250 \mathrm{ml}$ conical flasks; $1 \%$ inoculum) were grown on a rotary shaker at $30^{\circ} \mathrm{C}$. They were harvested (maximum of four flasks, minimum of two, depending on the cell density) after the indicated time intervals by centrifugation at $30000 \mathrm{~g}$ for $10 \mathrm{~min}$ at $5{ }^{\circ} \mathrm{C}$, resuspended in phosphate buffer, $\mathrm{pH} 8.0$ plus EDTA and NaF and then assayed for hydrogenase manometrically with methylene blue as the electron acceptor (see Methods). The culture turbidity was measured at $540 \mathrm{~nm}$. Hydrogenase activity; $\boldsymbol{\Delta}, A_{540}$.

(Table 1). These results are similar to those of Lee \& Wilson (1943) (Table 1, columns 2 and 3) and Green \& Wilson (1953) (Table 1, column 4). The $\mathrm{NO}_{3}{ }^{-}$-grown cells had grown in continuous culture for 86 to 87 generations before adapting to $\mathrm{NO}_{3}^{-}$and repressing nitrogenase. During this time, batch cultures inoculated from the continuous culture possessed hydrogenase activities as high as those in $\mathrm{N}_{2}$-fixing cells. After adaptation, the hydrogenase activity decreased to $48.5 \%$ (Table 1 ). Green \& Wilson (1953) showed that hydrogenase activity diminished as $\mathrm{N}_{2}$-fixing cultures aged, but the reverse occurred in $\mathrm{NH}_{4}{ }^{+}$-grown cells. This increase in $\mathrm{NH}_{4}{ }^{+}$-grown cells coincided with the disappearance of $\mathrm{NH}_{4}{ }^{+}$from the supernatant, again consistent with a relationship between hydrogenase and nitrogenase.

However, hydrogenase activities measured with methylene blue varied widely among replicate batch cultures, ranging between 473 and $967 \mathrm{nmol} \mathrm{H}_{2}$ absorbed (mg protein) ${ }^{-1}$ min $^{-1}$ for $\mathrm{N}_{2}$-grown cells, between 28 and 408 for $\mathrm{NH}_{4}{ }^{+}$-repressed cells and between 80 and 606 for $\mathrm{NO}_{3}^{-}$-repressed cells. Figure 1 indicates why this was so: consistent with Green \& Wilson's (1953) findings, hydrogenase activity changed markedly during batch growth, increasing during cell multiplication and declining in the stationary phase. A similar 


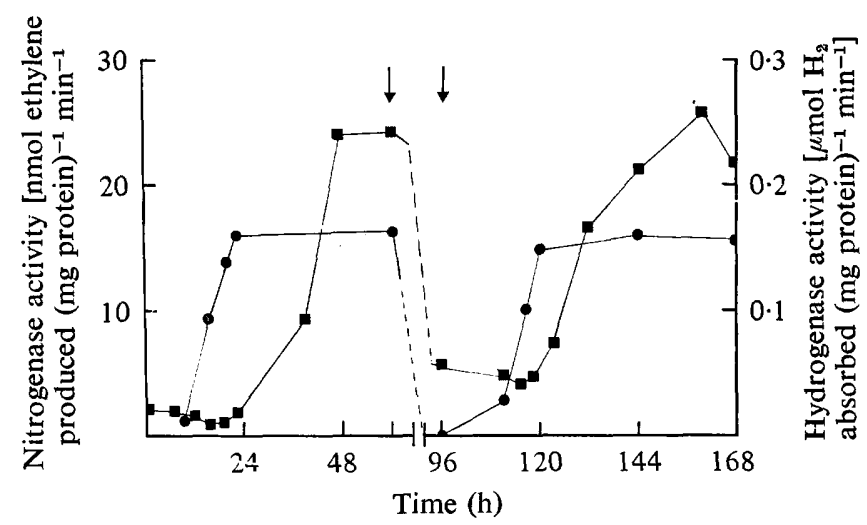

Fig. 2. Effects of nitrogen source on uptake hydrogenase and nitrogenase activities in carbonlimited $A$. chroococcum. Hydrogenase was assayed manometrically with methylene blue and nitrogenase was assayed by the rate of acetylene reduction at optimum $\mathrm{O}_{2}$ concentration (see Methods). At time zero, the ammonium acetate-dependent culture $\left(D=0.1 \mathrm{~h}^{-1}, \mathrm{pH} 7 \cdot 5\right)$ was shifted to nitrogen-free medium; the first arrow indicates the shift back to ammonium acetate and the second arrow the subsequent return to $\mathrm{N}_{2}$-dependent growth. The culture was carbon-limited because excess $\mathrm{O}_{2}$ was detected in the medium. $\mathbf{\square}$, Hydrogenase activity; $\bullet$, nitrogenase activity.

pattern was observed whether the $\mathrm{pH}$ was controlled $(\mathrm{pH} \mathrm{7.3)}$ or uncontrolled (changing from $\mathrm{pH} 7 \cdot 4$ to $6 \cdot 1$ during growth).

\section{Hydrogenase and nitrogenase activity in continuous cultures}

The $\mathrm{H}_{2}$-uptake activity of a given carbon- or sulphate-limited culture did not change significantly in the steady state. Different activities were observed in different cultures under similar nutrient limitations. Whether this was due to phenotypic variation among the populations or different physical parameters in the culture vessels is not known.

Carbon-limitation. Both the nitrogenase and the $\mathrm{H}_{2}$-uptake hydrogenase activities increased significantly during the transition from ammonium acetate- to $\mathrm{N}_{2}$-dependent growth in carbon-limited cultures; this increase was reversed during the transition back to $\mathrm{NH}_{4}{ }^{+}$-dependence but occurred again on transferring back to $\mathrm{N}_{2}$ utilization (Fig. 2). This pattern was also obtained with $\mathrm{NH}_{4} \mathrm{Cl}$ as the source of fixed nitrogen. The increase in hydrogenase activity commenced several hours later than the increase in nitrogenase activity, implying that the two enzymes were not derepressed co-ordinately. Specific activities of hydrogenase in carbon-limited, $\mathrm{N}_{2}$-fixing populations were slightly less than the lowest activity observed in early-stationary phase batch cultures.

Sulphate-limitation. Uptake hydrogenase activity in $\mathrm{N}_{2}$-grown sulphate-limited cultures was generally lower than that in carbon-limited cultures: ranging from 30 to 100 , compared with 60 to $275 \mathrm{nmol} \mathrm{H}_{2}$ absorbed (mg protein) ${ }^{-1} \mathrm{~min}^{-1}$ in the latter cultures. During the transition from $\mathrm{N}_{2}$ - to $\mathrm{NH}_{4}{ }^{+}$-supported growth there was a rapid decline in nitrogenase activity, faster than the washout time of the $\mathrm{N}_{2}$-fixing culture or the disappearance of nitrogenase peptides from the extracts. Hydrogenase activity, on the other hand, declined by $25 \%$ in $7 \mathrm{~h}$ but returned to the same level as that in $\mathrm{N}_{2}$-fixing cells at the steady state in $\mathrm{NH}_{4}{ }^{+}$-grown cultures (Fig. 3). A similar transient decline in uptake hydrogenase activity was observed during the reverse transition from $\mathrm{NH}_{4}{ }^{+}-$to $\mathrm{N}_{2}$-dependent growth. Measurements of $\mathrm{O}_{2}$-dependent $\mathrm{H}^{3} \mathrm{H}$ oxidation confirmed that the hydrogenase activity of sulphatelimited cells was independent of the nitrogen source.

Effect of dilution rate. The uptake hydrogenase activity of an $\mathrm{N}_{2}$-dependent, sulphatelimited population declined by $22 \%$ on changing the dilution rate from 0.05 to $0 \cdot 1 \mathrm{~h}^{-1}$ and 


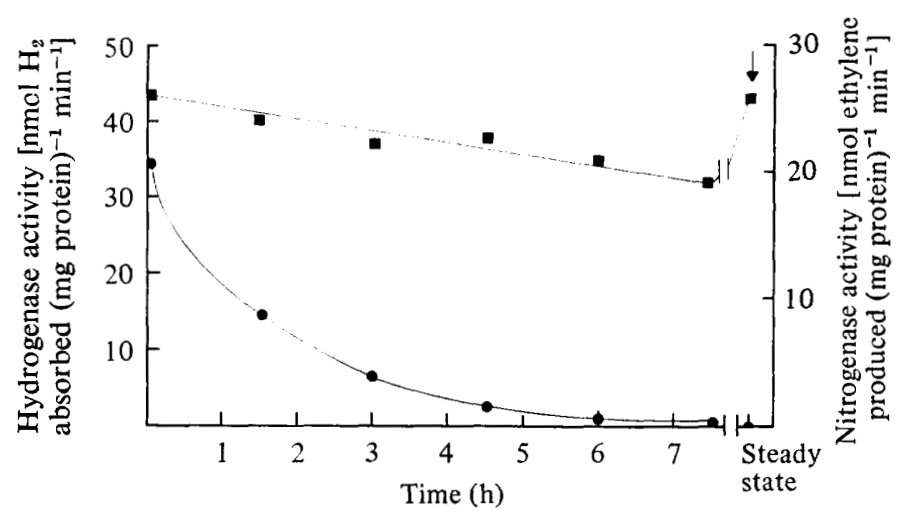

Fig. 3. Uptake hydrogenase and nitrogenase activity in sulphate-limited $A$. chroococcum during transition from $\mathrm{N}_{2}-$ to $\mathrm{NH}_{4}{ }^{+}$-dependent growth. Hydrogenase and nitrogenase were measured as described in the legend to Fig. 2 . The arrow indicates the steady state values under $\mathrm{NH}_{4}{ }^{+}$-grown conditions. $\square$, Hydrogenase activity; $\mathbf{0}$, nitrogenase activity.

Table 2. Effect of dilution rate on nitrogenase and hydrogenase activities in

$$
\mathrm{N}_{2} \text {-fixing sulphate-limited } \mathrm{A} \text {. chroococcum }
$$

Nitrogenase activity was determined in samples from continuous cultures in steady state as described in Methods; results are expressed as nmol acetylene reduced (mg protein) $)^{-1} \mathrm{~min}^{-1}$. Hydrogenase activity was measured manometrically with methylene blue as the electron acceptor; results are expressed as $\mathrm{nmol} \mathrm{H}_{2}$ absorbed (mg protein) ${ }^{-1} \mathrm{~min}^{-1}$.

$\begin{array}{ccc}\begin{array}{c}\text { Dilution rate } \\ \left(\mathrm{h}^{-1}\right)\end{array} & \begin{array}{c}\text { Hydrogenase } \\ \text { activities }\end{array} & \begin{array}{c}\text { Nitrogenase } \\ \text { activity }\end{array} \\ 0.05 & 139 & \text { NT } \\ & 140 & \\ 0.10 & 90 & 12.5 \\ & 115 & \\ 0.15 & 129 & 22.2 \\ 0.20 & 99 & \\ & 95 & 44.0 \\ & 108 & \\ & 117 & \end{array}$

thereafter remained approximately the same at dilution rates of 0.15 and $0.2 \mathrm{~h}^{-1}$. On the other hand, nitrogenase activity increased fourfold on increasing the dilution rate from $0 \cdot 1$ to $0.2 \mathrm{~h}^{-1}$ (Table 2). The percentage of nitrogenase peptides in the total cell extract also increased over this range of dilution rates. Hence, as in carbon-limited populations (Fig. 2), nitrogenase and uptake hydi-ogenase activities were not co-ordinately regulated in sulphatelimited $A$. chroococcum. Effects of dilution rate on carbon-limited populations were not studied.

Effect of $p H$. The transition from $\mathrm{N}_{2^{-}}$to ammonium acetate-dependent growth in sulphate-limited cultures caused an increase in pH from 6.7 to $7 \cdot 5$. However, the hydrogenase activity did not change during the transition between nitrogen sources when the $\mathrm{pH}$ was kept at $\mathrm{pH} 6.9$ by manual additions of $\mathrm{HCl}$. Hydrogenase activity is thus not permanently affected by $\mathrm{pH}$ changes of the culture medium between 6.7 and 7.4 in sulphate-limited cells. Furthermore, the $\mathrm{pH}$ change $(7 \cdot 5$ to $7 \cdot 0)$ accompanying the transition from $\mathrm{NH}_{4}{ }^{+}$- to $\mathrm{N}_{2}$-dependence in carbon-limited cultures preceded the onset of the increase 
in hydrogenase activities by almost two generation times. This again implies that this change in external pH did not affect hydrogenase activity. Lee \& Wilson (1943) also found that the $\mathrm{pH}$ of the culture within this range had no effect on the specific activity of hydrogenase in extracts from Azotobacter.

Effects of $\mathrm{H}_{2}$. Exposure of an ammonium acetate-supported carbon-limited culture to $5 \% \mathrm{H}_{2}$ in the atmosphere for $12 \mathrm{~h}$ doubled hydrogenase activity. No effect was observed on the uptake hydrogenase activity of a similarly treated ammonium acetate-supported sulphate-limited culture. The effects of $\mathrm{H}_{2}$ on hydrogenase activity in $\mathrm{N}_{2}$-dependent chemostat cultures were not studied.

\section{DISCUSSION}

The use of continuous culture techniques in this study has clearly overcome some of the disadvantages encountered in batch cultures of $A$. chroococcum, in which hydrogenase activities varied considerably between batches of the same age. Steady-state hydrogenase activities were consistent within a given chemostat run. For the purpose of this discussion we assume that the measured activity of hydrogenase related to the hydrogenase content and synthesis of active enzyme.

In carbon-limited chemostat cultures, in the batch cultures used by Wilson and his colleagues and in our stationary phase batch cultures, the uptake hydrogenase activity was greater under $\mathrm{N}_{2}$-fixing conditions than when nitrogenase synthesis was repressed by the source of fixed nitrogen. However, even in carbon-limited conditions, it is unlikely that the syntheses of nitrogenase and hydrogenase are controlled by the same regulator for two reasons: (i) $\mathrm{NH}_{4}{ }^{+}$represses hydrogenase synthesis 2- to 7-fold whereas it represses nitrogenase by more than $10^{4}$-fold; (ii) nitrogenase synthesis precedes hydrogenase synthesis by approximately $12 \mathrm{~h}$ (Fig. 2). The results in Fig. 2 suggest a more likely possibility: that hydrogen, a normal product of nitrogenase action, induces hydrogenase synthesis. The effect of exogenous $5 \% \mathrm{H}_{2}$ in augmenting the hydrogenase activity of $\mathrm{NH}_{4}{ }^{+}$-dependent carbon-limited populations supports this view. The effect of exogenous $\mathrm{H}_{2}$ was small compared with the effect of changing the nitrogen source from $\mathrm{NH}_{4}{ }^{+}$to $\mathrm{N}_{2}$, but the position is complicated by an inhibitory effect of excess exogenous $\mathrm{H}_{2}$ : increasing the $\mathrm{H}_{2}$ in the gas phase above $5 \%$ inhibited batch growth of $A$. chroococcum (A. van der Werf \& M. G. Yates, unpublished results) and decreased hydrogenase activity (Lee \& Wilson, 1943). It is therefore plausible that fixed nitrogen sources have no direct influence on hydrogenase synthesis but that derepression of nitrogenase leads to $\mathrm{H}_{2}$-induced synthesis of extra hydrogenase.

The specific activities of hydrogenase in carbon-limited $\mathrm{N}_{2}$-fixing chemostat cultures were generally higher than under other nutrient limitations and resembled those of batch cultures at the end of their growth curve, when carbon sources may be limiting. These observations support the view (Walker \& Yates, 1978) that hydrogenase synthesis in $A$. chroococcum is primarily repressed by carbon metabolites and that this process overrides the effects of nitrogen source discussed above.

Two other features of hydrogenase synthesis require explanation. Firstly, the decrease in hydrogenase activity upon increasing the dilution rate of sulphate-limited $\mathrm{N}_{2}$-fixing cells from 0.05 to $0.1 \mathrm{~h}^{-1}$ probably arose because the faster growth allowed a higher steady-state level of a carbon metabolite repressor than that necessary for maximum derepression. Secondly, nitrogenase activity declined faster than hydrogenase activity in carbon-limited cells during the transition from $\mathrm{N}_{2}$ - to $\mathrm{NH}_{4}{ }^{+}$-supported growth: nitrogenase activity declined to zero within $6 \mathrm{~h}$, faster than both the washout time and the rate of disappearance of nitrogenase peptides from the $\mathrm{N}_{2}$-fixing population, whereas hydrogenase activity declined at the same rate as the washout of $\mathrm{N}_{2}$-fixing cells. This is consistent with other reports that $\mathrm{NH}_{4}{ }^{+}$can specifically inhibit nitrogenase activity in Azotobacter species (L'vov et al., 1971; Drozd et al., 1972; Kleiner, 1975). 
We wish to thank Mrs Frances Campbell for technical assistance.

\section{REFERENCES}

BAKER, K. (1968). Low cost continuous culture apparatus. Laboratory Practice 17, 817-824.

BrotonEgoro, S. (1974). Nitrogen fixation and nitrogenase activity of Azotobacter chroococcum. Mededelingen van de Landbouwhoogeschool te Wageningen 74-10, 1-76.

Drozd, J. W., Tubi, R. S. \& Postgate, J. R. (1972). A chemostat study on the effect of fixed nitrogen sources on nitrogen fixation, membranes and free amino acids in Azotobacter chroococcum. Journal of General Microbiology 73, 221-232.

Green, M. \& Wilson, P. W. (1953). Hydrogenase and nitrogenase in Azotobacter. Journal of Bacteriology 65, 511-517.

KleINER, D. (1975). Ammonium uptake by nitrogenfixing bacteria. I. Azotobacter vinelandii. Archives of Microbiology 104, 163-169.

LeE, S. B. \& Wilson, P. W. (1943). Hydrogenase and nitrogen fixation by Azotobacter. Journal of Biological Chemistry 151, 377-385.

LeE, S. B., Wilson, J. B. \& Wilson, P. W. (1942). Mechanism of biological nitrogen fixation. X. Hydrogenase in cell-free extracts and intact cells of Azotobacter. Journal of Biological Chemistry 144, 273-281.

Lim, S. T. \& Shanmugam, K. T. (1979). Regulation of $\mathrm{H}_{2}$ utilisation in Rhizobium japonicum by cyclic AMP. Biochimica et biophysica acta 584, 479-492.

L'vov, N. P., Sergeev, N. S., Veinova, M. K., Shaposhnikov, G. L. \& Kretovich, N. L. (1971). Properties of the component of the nitrogenfixing enzymic system of Azotobacter vinelandii. Doklady Akademii Nauk CCCP 201 (6), 14931496.

Maier, R. J., Campbell, N. E. R., Hanus, F. J., Simpson, F. B., Russell, S. A. \& Evans, H. J.
(1978). Expression of hydrogenase activity in freeliving Rhizobium japonicum. Proceedings of the National Academy of Sciences of the United States of America 75, 3258-3262.

Maier, R. J., Hanus, F. J. \& Evans, H. J. (1979). Regulation of hydrogenase in Rhizobium japonicum. Journal of Bacteriology 137, 824-829.

Newton, J. W., Wilson, P. W. \& Burris, R. H. (1953). Direct demonstration of ammonia as an intermediate in nitrogen fixation by Azotobacter. Journal of Biological Chemistry 204, 445-451.

RoBSON, R. L. (1979). $\mathrm{O}_{2}$-repression of nitrogenase synthesis in Azotobacter chroococcum. FEMS Microbiology Letters 5, 259-262.

SCHLEGEL, H. \& EbERHARDT, U. (1972). Regulatory phenomena in the metabolism of the Knallgas bacteria. Advances in Microbicil Physiology 3, 159-196.

Smith, L. A., Hill, S. \& Yates, M. G. (1976). Inhibition by acetylene of conventional hydrogenase in nitrogen fixing bacteria. Nature, London 262, 209-210.

WALKeR, C. C. \& YATES, M. G. (1978). The hydrogen cycle in nitrogen-fixing Azotobacter chroococcum. Biochimie 60, 225-232.

Wilson, J. B., Lee, S. B. \& Wilson, P. W. (1942). Mechanism of biological nitrogen fixation. IX. Properties of hydrogenase in Azotobacter. Journal of Biological Chemistry 144, 265-271.

Yates, M. G., Partridge, C. D. P., Walker, C. C., van der Werf, A., Campbell, F. O. \& Postgate, J. R. (1980). Aspects of hydrogen metabolism in $\mathrm{N}_{2}$-fixing Azotobacter chroococcum. In Proceedings of the Phytochemical Society of Europe, vol. 18 (in the Press). Edited by W. D. P. Stewart \& J. R. Gallon. London: Academic Press. 